\title{
The Twinning of Inflation and Unemployment Phenomena in Saudi Arabia: Phillips Curve Perspective
}

\author{
Abla A.H. Bokhari
}

ABSTRACT

\begin{abstract}
The global economy has witnessed many economic fluctuations and waves of inflation and recession. With the consideration of achieving price stability as a primary goal of the economic policies, any attempt to eliminate inflation means accepting higher rates of unemployment, and vice versa. This conflict relationship was explained by the Economist "Phillips", who developed the inflation/unemployment curve. After the emergence of the stagflation phenomenon, this relationship became an object of argument and skepticism. Therefore, the key point of this study is to investigate the tradeoff relationship between inflation and unemployment in the Kingdom of Saudi Arabia for the period 1988-2017. The co-integration and error correction approaches have been utilized, to determine the equilibrium relations in the long-run and short-run, and the causality direction between the two phenomena. Johansen test indicated that a long-run co-integration relationship was existed. Based on Vector Error Correction Model (VECM), results provide evidence in favor of the long-runs negative causation running from unemployment to inflation. Contrary to expectation, there was no significant evidence of short-run tradeoff between unemployment and inflation in the Saudi economy.
\end{abstract}

KEY WORDS: $\quad$ Inflation, Unemployment, Phillips Curve, Causality Analysis, Saudi Arabia.

JEL Classification: E4, E5, E6.

King Abdulaziz University, Jeddah, Saudi Arabia

\section{Introduction}

A widespread of governments and economists' attention has been given to the relationship between inflation and unemployment as one of the most important macroeconomic issue. However, this macroeconomic issue seems to bring about contradictory views. Unemployment can be considered as the first problem that threatens the economic and social security of a country. It engenders welfare loss in terms of less output and it leads to lower income and well-being (Umaru \& Zubairu 2012). Inflation is a considerable problem

Correspondence concerning this article should be addressed to: Abla A.H. Bokhari, King Abdulaziz University, Jeddah, Saudi Arabia. E-mail: abokhari@kau.edu.sa due to its reflection on the standards of living, which has been observed to weaken the purchasing power and the failure of economic policies in achieving the stability of prices. Certainly, the government strives to maintain a stable domestic price level and fullemployment. The policies for the avoidance of inflation and unemployment are required to achieve these goals. Arguments over the Phillips curve has achieved thrust since the financial crisis in 2008. In the development of the downturn that followed the crisis, inflation in advanced countries did not decrease much as the conventional Phillip curve and previous experiences would forecast, provided the length and severity of the recession (Riggi \& Venditti, 2015).

Therefore, the study has intended to assess the asso- 
ciation of inflation and unemployment phenomena in Saudi Arabia. The study has opted Phillips curve perspective to explain the inflation dynamics that seek to assess and explain the development of the unemployment rate.

Taking into consideration the context of Saudi Arabia, it is one of the most oil-rich countries in the world. In 2014, the employment rate among Saudis was $11.8 \%$ (Alamoudi et al., 2015). Similarly, inflation has remained relatively high, calculating an average of $4.17 \%$ during the period from 2007 to 2013 (Alhamad 2014). In 2008 Saudi Arabian inflation rate reached the high level of $9.87 \%$, which considers the highest rate since its peak of 1977 (11.4\%) (World Bank, 2008b). However, high levels of unemployment for past decade have also been witnessed by the Kingdom of Saudi Arabia. According to the Saudi Ministry of Labor (2012), unemployment rate has reached $12.4 \%$ during the period of 2011. Like many other governments whose countries suffer from inflation or unemployment, the Kingdom faces several social and economic problems, resulting from these two phenomena. It seems to face the judgments and protests from the public, condemning failure of the government's policies to overcome the issue of unemployment and inflation. The inverse relationship between these two phenomena creates a contradiction in the economic goals and policies, which directed to overcome each of them. The study has contributed to examine the relationship between unemployment and inflation in the Kingdom of Saudi Arabia. Moreover, it also aimed to investigate the existence of a twinning relationship between the two phenomena in both short-run and long-run.

Investigating the relationship of inflation and unemployment in Kingdom of Saudi Arabia has always been of considerable interest. To the best of knowledge, there are no previous practical studies conducted about this issue in Saudi Arabia,with exception of Ossman (2014) -which mentioned that unemployment does not predict the rates of inflation in Saudi Arabia. Hence, the main objective of this paper is to econometrically disclose the twinning nature of the relationship between inflation and unemployment in Saudi Arabia. This relationship has been evaluated by explaining the results that may confirm or contradict the applicability of Philips Curve; the matter that helps decision makers in setting out remedial policies for two problems. Accordingly, the following hypotheses have been tested:

$\mathrm{H}_{\mathrm{Al}}$ : Unemployment rate affects inflation rate inversely in Saudi Arabia.

$\mathrm{H}_{\mathrm{A} 2}$ : Inflation rate affects unemployment rate inversely in Saudi Arabia.

$\mathrm{H}_{\mathrm{A} 3}$ : There is a long-run inverse causative relationship between inflation and unemployment rates.

\section{Theoretical Background}

According to the classical theory, inflation is determined by the integration between money supply and money demand. If the supply money is rising too fast, inflation results. Consequently, there is no relationship between inflation and unemployment in classical thought and prolonged unemployment considered to be voluntary, which can be observed from Figure 1.

After the Great Depression of 1929, classic economists failed to interpret this worldwide phenomenon of "failure to provide for full employment" (Davidson, 2009). The revolutionary analysis of Keynes theory threw down the defiance to classical thought, providing claims against the applicability of Say's Law. John Maynard Keynes (1883-1646) rejected the classical mechanism and the "laissez-faire" (French phrase for "leave alone") free markets. The massive unemployment that convoyed the depression, cast down doubt on the validity of older mechanisms in market's adjustments; the role of government in handling the economy, and creating market demand are required. Equilibrium can be achieved at a lower or a higher level than the full employment; because full employment is only possible, if total demand is adequate (Davidson, 2009).

The chief determinant of an economy's stability, according to Keynesian thinking, is the level of total demand. If the total expenditure on goods and services is inadequate, unemployment will take place, but if this expenditure is excessive, inflation will rise. As the attendant circumstances of the Keynesian thought had been marked by the rule of recession and widespread unemployment, the inflexibility of prices and wages has led to the disappearance of inflation. The curve of unemployment and inflation can be observed from Figure 2.

After Second World War, the Western countries 


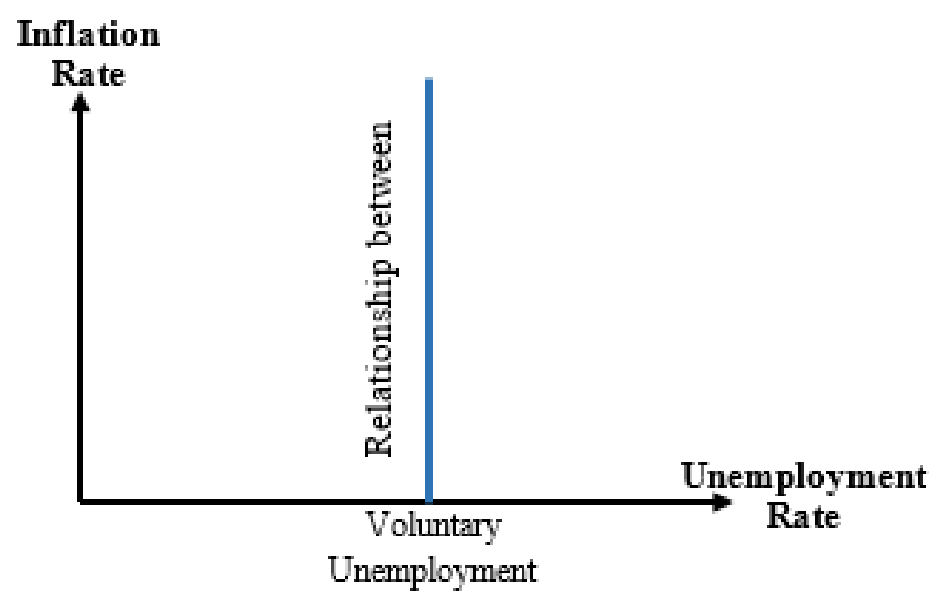

Figure 1. Relationship between inflation and unemployment in classic thinking.

\section{Inflation \\ Rate}

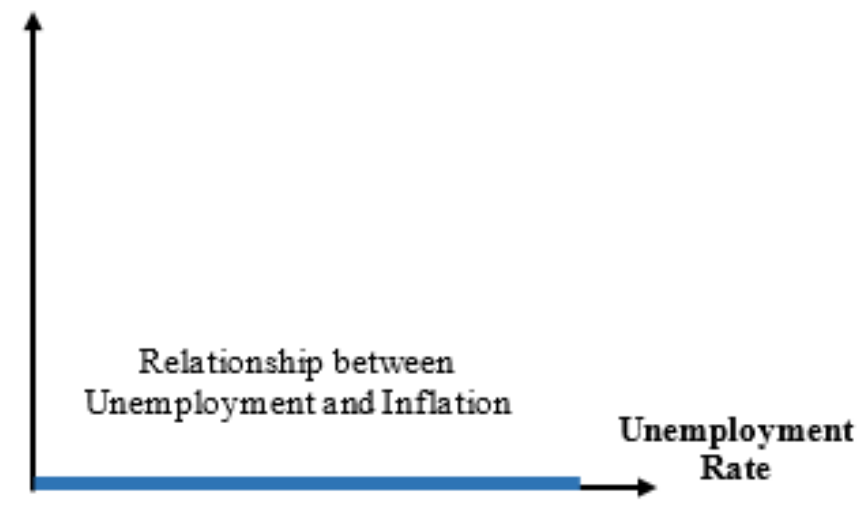

Figure 2. Relationship between inflation and unemployment in Keynes'thinking. 
regained its recovery from recession, but the problem of inflation seems to be emerged with remarkable rates. Consequently, economists were encouraged to investigate the nature of relationship between inflation and unemployment. It was generally imagined that economies faced either unemployment or inflation. In 1958, Alban William Phillips published the empirical analysis on the relationship between the annual wage inflation and unemployment rates in the UK over the period 1861-1957, plotting it on a scatter diagram "Phillip Curve" (Nitzan, 1990). Phillips (1958) revealed that wages tended to increase at low rates of unemployment. It has been indicated that in cases of economic boom, total demand on various goods and services increases, which results in enhancing the demand for manpower and so, unemployment decreases. Due to increasing demand of manpower, wages and income increase, so total demand increase resulting prices' rise, and vice versa. Phillips (1958) stated that: "When the demand for a commodity or service is high relative to the supply of it, the price is expected to rise. The higher the rate of increase, the greater is excess demand. Conversely, when the demand is low relatively to the supply, the prices are expected to decline. The greater the decline in prices, the higher is the deficiency of demand. It seems plausible that this principle should operate as one of the factors determining the rate of change of money wage rates, which are the price of labor services". Accordingly, the inverse relationship between unemployment rate and inflation rate (wages) has been presented in Figure 3.

Phillips (1958) concluded that by assuming an annual increase in productivity by $2 \%$, unemployment rate would not exceed $2.5 \%$, if the aggregate demand were held in reserve maintaining a stable level of prices. It is also necessary to accept $5.5 \%$ of unemployment to keep the demand at the value that maintains the stability of wages (Phillip, 1958). Keeping in mind that when the inflation rate, which is associated with the natural unemployment's rate is too high, it could be reduced by allowing greater rate of unemployment. It might result to decrease the nominal wages, therefore, the relationship can only be achieved in the shortrun. In the long-run, there is no trade-off between inflation and unemployment, thus, the Phillips Curve becomes vertical. Modifying Phillips Curve's formulation, Samuelson and Solow (1960) proposed a macroeconomic framework that links unemployment with the overall price inflation, instead of the wage inflation.

\section{Related Research}

The theoretical interests on the relationship among unemployment and inflation have been held by observations, stretching over a longer period. Precisely in 1958, the New Zealand economist Alban William Phillips analyzed the behavior of unemployment rates and wages in United Kingdom. As mentioned by Phillips "there is a clear tendency for the rate of change of money wage rates to be high when unemployment is low and to be low or negative when unemployment is high" (Phillips, 1958). Moreover, Phillips (1958) also indicated that the change of money wage rates at any certain level of unemployment can be below or above the average level of unemployment, during the downswing or upswing of a trade cycle respectively. Presently, there are turbulent debates about the validity of the Phillips curve, which are observed to have an influence on the relationship of inflation and unemployment (Lisý \& Muchová, 2014).

The modified forms of Phillip curve distinguished between the short-run and long-run relationship of inflation and unemployment. From the empirical and theoretical literature, it can be observed that Phillips curve can only be applied in the short term because there is generally an inverse relationship between the rates of inflation and unemployment. A study has been carried out by Ormerod et al. (2013) with respect to the association of inflation and unemployment and the instability of Phillips Curve. It has been evaluated through outcomes that the relationship of unemployment and inflation is relatively unstable, particularly in the short-run. According to Umaru and Zubairu (2012), there is no causation among the inflation and unemployment in long-run. Yet, the authenticity of twinning these two phenomena and trade-off between them still dominates the consciousness of economists, governments, and policy makers.

Mahmood et al. (2013) proposed that "inflation is a situation in an economy where the demand of money is fewer than its supply", or "an increase in the general level of prices in an economy that is sus- 


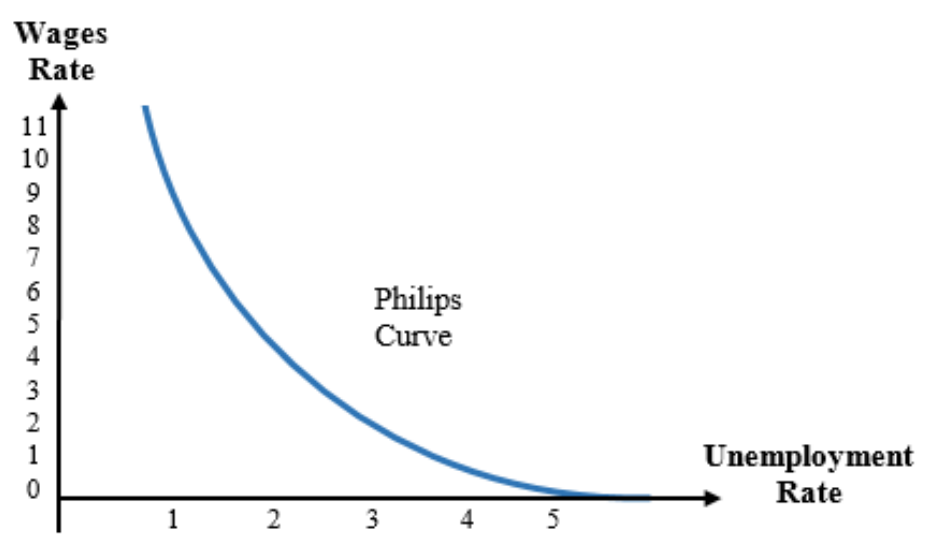

Figure 3. Phillips curve.

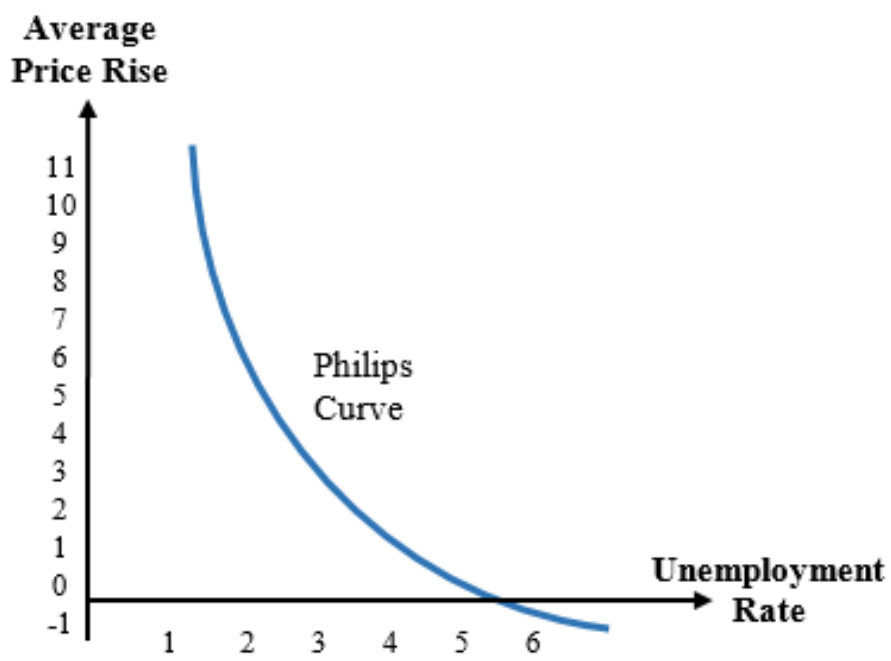

Figure 4. The modified Phillips curve. 
tained over a period of time" (Pass et al. 1991). However, there are different measures, which can be used for the computation of the rates of inflation. Some of these methods include Consumer Price Index (CPI), Producer Price Index (PPI), and Retail Price Index (RPI). The concept of unemployment is also defined as "the non-utilization of labor and capital resources, as a result of which the actual output of economy is below its potential gross national product" (Pass et al. 1991). International Labour Organization (ILO) simply defines the unemployed person as the "persons who only meet the criteria of "without work" and "currently available for work" (International Labour Organization, 2012). In 2015, the global unemployment rate stood at 5.8\%, accounting for 197.1 million unemployed persons. This number is expected to rise by 2.3 and 1.1 million in 2016 and 2017 respectively (International Labour Organization 2016). However, the size of unemployment is determined less than its actual size in many cases. Some categories of the unemployed are missed out 'hidden unemployment' and not included in official statistics. For instance, marginally attached labor; the discouraged workers who have lost their job, are not classified neither as unemployed nor a part of the labor force. On the other hand, under-employed have been classified as the individuals who seek full-time job, but obliged to settle for a part-time. There are also economically inactive people who cannot actively search for a job for any reason. Real unemployment rate has been observed as twice of the official rate (5.5\%) in the United States, and nearly three times of it in Japan. Generally, the real unemployment rate is approximately double the official rate across North America, Europe and Australia (Systemic Disorder 2015).

In the developing countries, the situation worsened with randomness of estimation and the lack of uniform scientific and official concept for unemployment. In Saudi Arabia, foreigners accounted around $48.6 \%$ of total population. Unemployment rate among foreigners is $0.3 \%$, while it reaches $11.7 \%$ among Saudi individuals, the actual unemployment rate with the exclusion of the hidden unemployment, and all other marginally attached workers the will be much higher than the rate $(5.7 \%)$, announced officially (Saudi Arabian Monetary Agency 2015).
The existence of Phillips Curve's relation has been scrutinized by various researchers (Llaudes, 2005; Mankiw, 2001; Stock \& Watson, 2008). Samuelson and Solow (1960) tried to examine the relationship between unemployment and inflation in the economy of United States. The findings concluded that in the time series of United States, a trade-off relationship of the Phillips curve exists between the rates of inflation and unemployment. The recommendation was recognized by many economists and realized by policymakers. A noteworthy contribution to the Phillips Curve was presented by Solow (1970) and Gordon (1970), who confirmed the existence of an inverse trade-off relationship between inflation and unemployment in the United States.

Friedman (1968) claimed that there could be negative association among the rates of inflation and unemployment in the case of short-run. In contrast, there is no permanent trade-off between them, even under high rates of inflation in long-run. In this case, Phillips Curve has been observed as vertical. Accordingly, policy makers possibly will direct their monetary policy without considering negative influences on the rates of unemployment. The term "natural rate of unemployment" was primarily addressed by Friedman (1968), stating that:

"It is the level that would be ground out by the Walrasian system of general equilibrium equations, provided there is embedded in them the actual structural characteristics of labor and commodity markets, including market imperfections, stochastic variability in demands and supplies, the cost of gathering information about job vacancies and labor avail-abilities, the costs of mobility, and so on (p. 8)".

The Monetarists (extension of the classical school of thought, as Milton Freidman, Anna Schwartz, Phillip Cagan, Karl Brunner, and others), clarified that the traditional Phillips curve is miss-specified. Therefore, they provided an alternative concept of "the expectations-augmented Phillips curve", which implied that if unemployment is above the natural rate, inflation increases, and vice versa. The natural unemployment rate comprises frictional, structural, and voluntary unemployment. However, economists referred the increase of the natural rate of unemployment to several factors, such as changing in 
the structures of labor markets, oil price shock, increased female, youth and part-time workers' participation in labor market, occupancy rate changes, unemployment insurance, trade unions' power, higher marginal tax rates (Cashell, 2004; Friedman, 1977; Hall, 1979).

One more criticism of the Phillips curve is known as "Lucas critique", against which Lucas (1976) has brought about a revolutionary development through the findings. It has been argued that expectations play a crucial role in influencing all sorts of economic behavior. The study of Lucas (1972) assessed the rational expectations hypothesis to provide the first theoretical explanation for sloping of Phillips curve in the short-run, and being vertical in the long-run. With the strong criticism on the existence of "Phillips curve", Lucas's (1972) theoretical model generated time series, from which inflation and employment were positively correlated. Despite of any criticisms, the Phillips curves "still plays a prominent role in macroeconomic theory and associated empirical work" (Hart, 2003).

King and Watson (1994) verified the existence of Phillips curve, by applying the post-war macroeconomic data of the United States. An empirical proof was provided for the existence of trade-off relationship between inflation and unemployment. As Hogan (1998) pointed out, there is a significant and negative relationship between inflation and unemployment, even though the traditional Phillips Curve appeared to be over predicting regarding the rate of inflation. In comparison, unlike the assumptions of Phillips Curve, a positive influence of inflation on unemployment was found in the United States by Kitov (2006). Unlike the Phillips Curve, the outcomes of Kitov (2006) revealed the existence of a slowing linear relationship between inflation, unemployment, and manpower. Any changes in the manpower lead to a change in both of unemployment and inflation for five and six years respectively in Germany; whereas, unemployment affects inflation for the following year. Furthermore, another study conducted by Kitov et al. (2007) has demonstrated a linear association among inflation and unemployment of France, during the time span of 1973-2004. It suggested the existence of the integrated linear relationship between unemployment, inflation and manpower. Nevertheless, Kitov and Kitov (2013) indicated that the Phillips curve for Japan supports the original concept's hypotheses, saying that an enhancement of unemployment results in decreasing inflation.

Stephanides (2006) investigated the relationship between inflation and unemployment rates in three leading countries, including EU-15, USA, and Japan. The study has shown that there is a strong trade-off between unemployment and inflation; there were other periods where both unemployment and inflation are changing in the same direction. Furuoka (2007) questioned whether there is really an existence of Phillip Curve. A long-run trade-off between inflation and unemployment was found in Malaysia. However, Furuoka (2008) confirmed that there is no causal relationship between the rates of inflation and rates of unemployment in the Philippines. The findings of the Error Correction Model of Furuoka and Munir's study (2014) indicated the existence of short-run influence of the rate of unemployment on the rate of inflation, as well as the existence of long-run relationship.

Karahan et al. (2012) affirmed the existence of an inverse relationship between unemployment and inflation in the short-run. On the contrary, it has also been evaluated that there is no relationship in the long-run in Turkey. Umaru and Zubairu (2012) examined the relationship between unemployment and inflation in the Nigerian Economy during the period 1977 -2009. Results revealed the existence of an inverse relationship between inflation and unemployment. Co-integration test confirmed the existence of a long-run integrated relationship between the two factors. Similarly, Haider and Dutta (2012) investigated the validity of the Phillips curve's hypothesis for the relationship between inflation and unemployment in Bangladesh during the period 1987-2009. The results revealed the negativity of relationship between inflation and unemployment. Similarly, Mahmood et al. (2013) indicated that the rates of unemployment are negatively related to inflation rates. Previous studies indicated the relationship between the Inflation and Unemployment Phenomena in different countries of the world (Furuoka, 2007; Furuoka \& Munir, 2014; Kitov et al. 2007; Stepharides, 2006;. 
To the best of our knowledge, this is the first study to consider investigating the relationship between unemployment and inflation in the Kingdom of Saudi Arabia, except the study of Ossman (2014). Yet, there are several studies that have been carried on, but to study either inflation (Al-Bassam, 1999; Al Khateeb \& Malki, 2014; Ramady, 2009;) or unemployment (Al Omran, 2010; Meteb, 2017 Ramady, 2013) separately. Osman (2014) investigates the effect of unemployment fluctuations on aggregate expenditure, interest, inflation and exchange rates in three of the Gulf Cooperation Council (GCC) countries, namely Saudi Arabia, Qatar, and United Arab Emirates. The results failed to find any evidence of significant relationship between the previous variables and unemployment. Consequently, Unemployment rates are not significantly related to inflation rates in Kingdom of Saudi Arabia.

To Al Omran (2010), one of the dreading results of reforms' efforts to solve unemployment is its impact on inflation. Concerning with unemployment as a serious issue for the youth of Saudi Arabia, be explains that Saudis were initially encouraged into better paying jobs, particularly in the public sector. At the same time, the massive incursion of unskilled foreign workers bring about a depressed levels of wages in private sector. Metab (2017) confirms the absence of magnetism for Saudis to work in the private sector jobs, with the relatively low wages compared to the public sector. Saudi workers do not satisfy the skills desired by the private sector. Consequently, the government be supposed to encourage private sector to employ Saudis through generating new job opportunities or substituting foreign employees by Saudis (Saudization programme). Nevertheless, Ramady (2013) indicates that implementation of Saudization policies to face unemployment, necessitates the creation of new jobs opportunities for Saudi labor instead of replacing the existing non-Saudi labor's job.

In indicating the explanatory variables of inflation, Al-Bassam (1999) finds Saudi Riyal/U.S. dollar exchange rate, money supply and real income growth rates to be with the most significant impacts. He concludes that inflation does not generated only by domestic sources, but also by external factors, namely foreign exchange rate, interest rate, and im- ported inflation. Yet growth in money supply is the most important source of inflation in Saudi Arabia. Likewise, Ramady (2009) explains the causes of inflation as a social concern that affected Saudi household's economic wellbeing. He found that inflation is influenced by exogenous variables, namely money supply, interest rate, and dollar pegged exchange rate. Al Khateeb (2014) provides several options for Saudi Government to dominate inflation. Through fiscal policy, public expenditure can be reduced and taxes can be raised. Similar to Ramady's opinion, He believes that these instruments are not preferred, as it may negatively affects economic and social development. Monetary policy would rather be employed to control inflation, by which Saudi Arabian Monetary Agency (SAMA) may control interest rate and reserves requirements.

This study has been carried out to make a contribution to the existing literature by investigating the existence of trade-off and twining relationship between inflation and unemployment in the Kingdom of Saudi Arabia.

\section{Econometric Methodology}

Unlike the traditional econometric statistical models, the co-integration analysis measures the actual relationship between the factors, particularly on the long run, whereas series are not stable on the short run but they become stable on the long run. The application of Granger Causality approach and Johansen's Co-integration approach has been employed to the two variables (inflation rate and unemployment rate). The methodology first requires evaluation the series stationarity and defines the degree of integration. For this purpose both Augmented Dickey-Fuller (ADF) and PhillipsPerron (PP) tests will be utilized. Johansen test has investigated the existence of co-integration by determining how many co-integrating vectors are present. It estimates all the different relationships. Through Johansen test, the long-run equilibrium relationship has been examined. After that, the integrating relationship between the two factors has been verified. Vector Error Correction Model (VECM) has also been used to estimate both shortrun and long-run impact of each variable's time series on the other, and to define the direction 
of the relationship and to determine whether it is a unidirectional relationship or a bidirectional relationship. Impulse response analysis is used in to explain this relationship.

\section{Data}

Annual data for the rates of inflation and unemployment in Saudi Arabia have been obtained from the World Bank Data (2018a, 2018b) for the period 1988-2017. Lack of sufficient data of Saudi Arabian unemployment enforce us to narrow the sample period to the maximum time series can be obtained. International Labour Organization's definition of unemployment has been adopted, according to which, "unemployment rate is the share of the labor force that is without work but available for and seeking employment" (Chaal-Dabi et al, 2014). Unemployment rates among Saudi nationals is not available, except for the late few years. Accordingly, the announced rate of unemployment may be misleading, taking into consideration that most of foreigners coming to the Kingdom are employed (very low rate of unemployment).
On the other hand, the definition of inflation has been adopted from the International Monetary Fund definition. Measured by the Consumer Price Index (CPI), inflation refers to "the annual percentage change in the cost to the average consumer of acquiring a basket of goods and services that may be fixed or changed at specified intervals, such as yearly" (World Bank 2014, p. 81).

\section{Results and Discussion}

In order to investigate the relationship between unemployment and inflation, the simple Phillips Curve could be estimated by utilizing following equations:

$I R_{t}=\propto_{1}+\beta_{1} U R_{t}+\varepsilon_{1 t}$

$U R_{t}=\propto_{2}+\beta_{2} I R_{t}+\varepsilon_{2 t}$

Where $\alpha$ denotes the constant, and $\beta$ is the slope coefficient. $I R$ is Inflation Rate and $U R$ is Unemployment Rate in Saudi Arabia in the year t. The random error term is $\varepsilon$. Inflation rates in terms

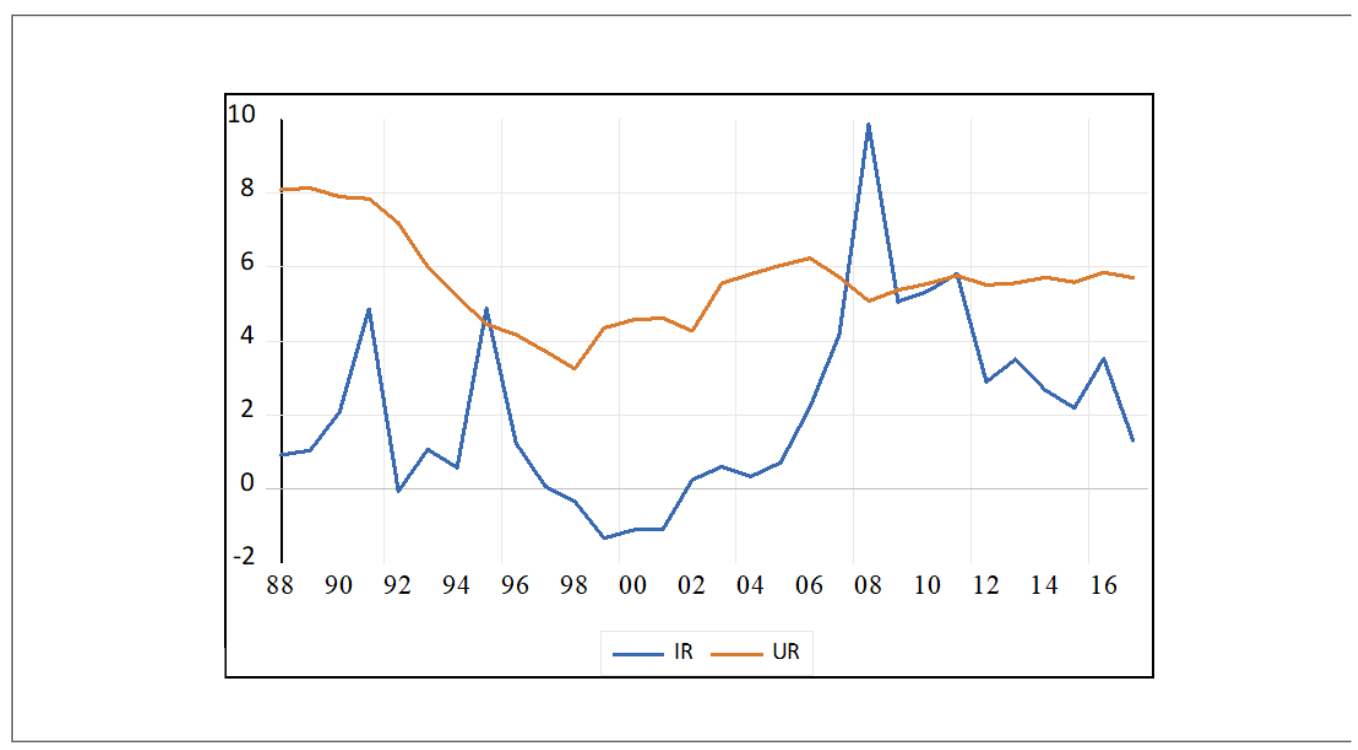

Figure 5. Inflation and Unemployment Rates in Saudi Arabia 
of CPI (Consumer Price Index) fluctuated from $0.91 \%$ in 1988 to $1.3 \%$ in 2017, while unemployment rate fluctuated during the same period from $8.1 \%$ in 1988 to 5.7 in 2017, which can be observed from Figure 5. Average rate of inflation was $2.1 \%$ for the period $1988-2017$, with a minimum rate of $-1.35 \%$ in 1999 , and a maximum rate of $9.9 \%$ in 2008 . The average rate of unemployment calculated at 5.63\%. It reached the maximum level (8.15\%) in 1989, and reached its minimum level (3.25\%) in 1998, as shown in Table 1.

The first step of the study is implementing regression to examine the series stationary; however, the model is shown to be stable as in Figure 6, according to CUSUM stability test. The Dickey-Fuller (ADF) unit root test (Dickey and Fuller, 1981) and the Phillips-Perron (PP) test (Phiilips \& Perron, 1988) have been utilized to check whether these two series are stationary or nonstationary. The tests' results indicated that inflation rate have a unit root; it is non-stationary in nature (at level). Meanwhile, unemployment rate does not have a unit root (intercept/no trend and intercept/tend). When the first differences were used, both time series became stationary, as shown in Table 2 .

Due to the instability in estimating this relationship in the presence of any structural break, we implement Bai and Perron's procedure. Inflation appears to have two main breaks in 2007 and 2012, while unemployment shows two other breaks in 1993 and 2003. A single structural shock, which is in 2007, is identified by the test for the inflation-unemployment relationship, as shown in table 3. Following the negative aggregate demand in 2007, Saudi Arabia benefited from the increase of oil prices during 20072008, and expanded its government expenditure (Al Rasasi \& Banafea, 2015). Inflation has risen sharply, while the unemployment rate has dropped significantly. SAMBA inflation report (2010) confirms that the 2007-2008 high inflation was basically a result of exogenous shocks as the trading partners' inflation, food prices, and the exchange rate. The excess demand was generally equalized through a higher spending on imports; yet, it did have an effect on inflationary pressures as a result of increases in rents.

Thus, it is important to consider the presence of this structural break (2007) in order to get the best possible results. After verifying the stability of study factors at the first difference, the second step was selecting the optimal lag length using both Akaike
Information Criterion (AIC) and Scwarz Information Critierion (SC). Table 4 shows that the optimal lag selected to be 1 year.

Johansen co-integration test (Johansen, 1988) has been used to examine the long-run movement of selected variables. It has been evaluated through outcomes that based on trace test there is two cointegrated equations, meanwhile the max-eigen test indicates no cointegration between inflation and unemployment. Given the preference for the trace test (Lütkepohl et al., 2002), we can reject the null hypothesis of no cointegration, for the favor of the alternative. Coefficient is reversed in the long-run $(-0.8777)$, meaning that falling in inflation will be associated with a rise in inflation and verse versa. This consistent with the theoretical evidence regarding the inverse relationship between inflation and unemployment, provides evidence in favor a long-run cointegration relationship between the two variables.

The existence of a co-integration equation indicates the existence of long-run relationships, while shortrun relationship can be tested through Vector Error Correction Model (VECM). According to the VECM. Equilivant to literature, but unlike some studies, such as of Lucas (1972), Hogan (1998), Kitov (2002) and Stephaides (2006), a negative relationship is indicated between inflation and unemployment, confirming the study hypothesis (HA1 \& HA2). The estimated model with $I R$ as the target variable is:

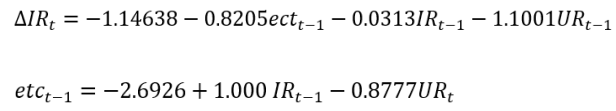

What is surprising, is that Wald test based on VECM result indicates that no causality between inflation and unemployment in the short-run. But on the long-run, the hypothesis (HA3) of inverse causative relationship between inflation and unemployment rates is existed in Saudi Arabia, running from unemployment to inflation. However, error correction term is negative and significant. The model's residuals were checked for autoregressive (Serial correlation LM test) and heteroscedasticity.

Figure 8 plots the impulse responses as applied in VECM for Saudi Arabian inflation and unemployment over the horizon of 10 years. It indicates that a unit of standard error shock of inflation corresponds to 
Table 1. Descriptive Statistics

\begin{tabular}{|c|c|c|}
\hline & Inflation & Unemployment \\
\hline Mean & 2.100500 & 5.633000 \\
\hline Median & 1.261000 & 5.580000 \\
\hline Maximum & 9.869000 & 8.150000 \\
\hline Minimum & -1.348000 & 3.247000 \\
\hline Std. Dev. & 2.518278 & 1.244922 \\
\hline Skewness & 1.030685 & 0.462507 \\
\hline Kurtosis & 3.547022 & 2.904233 \\
\hline Jarque-Bera & 6.868352 & 1.081029 \\
\hline Probability & 0.032252 & 0.582449 \\
\hline Sum & 63.01500 & 168.9900 \\
\hline Sum Sq. Dev. & 183.9099 & 44.94511 \\
\hline Total Observations & 30 & 30 \\
\hline
\end{tabular}

Table 2. Augmented Dickey - Fuller for Unit Root

At Level

$\begin{array}{ccccccc}\text { Variables } & \begin{array}{c}\text { Intercept/No } \\ \text { Trend }\end{array} & \begin{array}{c}\text { Intercept/ } \\ \text { Trend }\end{array} & \begin{array}{c}\text { No Intercept/ } \\ \text { No Trend }\end{array} & \begin{array}{c}\text { Intercept/ } \\ \text { No Trend }\end{array} & \begin{array}{c}\text { Intercept/ } \\ \text { Trend }\end{array} & \begin{array}{c}\text { No Intercept/ } \\ \text { No Trend }\end{array} \\ \text { IR } \text { t-stat. } & -2.653614 & -2.750905 & -1.933967 & -7.186721 & -7.056641 & -7.324312 \\ \text { Prob. } & (0.0943) & (0.2253) & (0.0520) & (0.0000) & (0.0000) & (0.0000) \\ \text { UR t-stat. } & -2.108682 & -1.684997 & -1.273053 & -3.691413 & -3.990379 & -3.680138 \\ \text { Prob. } & (0.2428) & (0.7320) & (0.1823) & (0.0099) & (0.0211) & (0.0007)\end{array}$




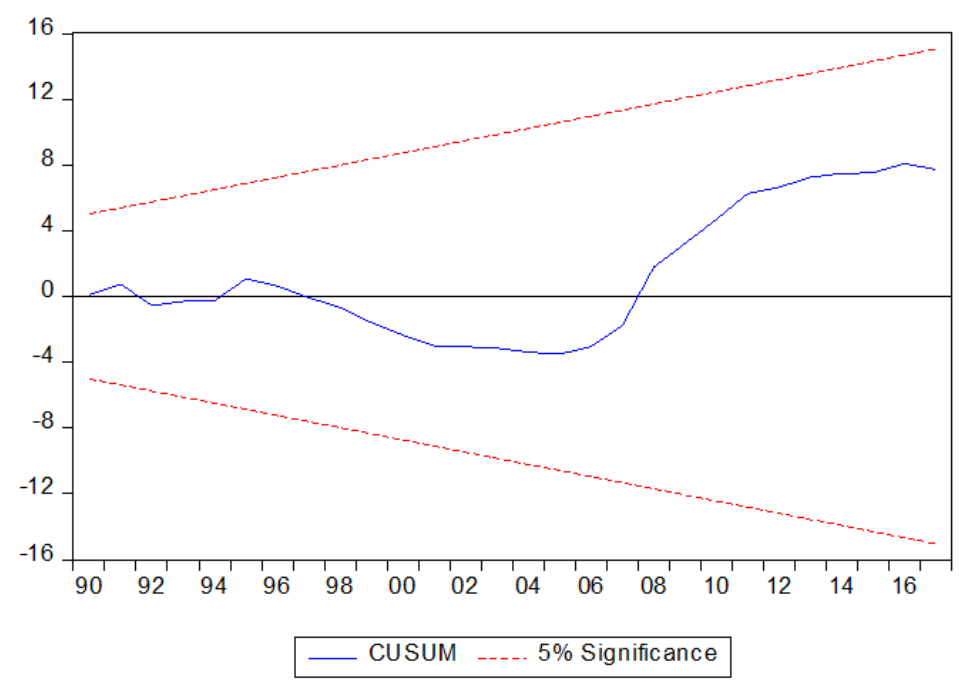

Figure 6. Model stability CUSUM test.

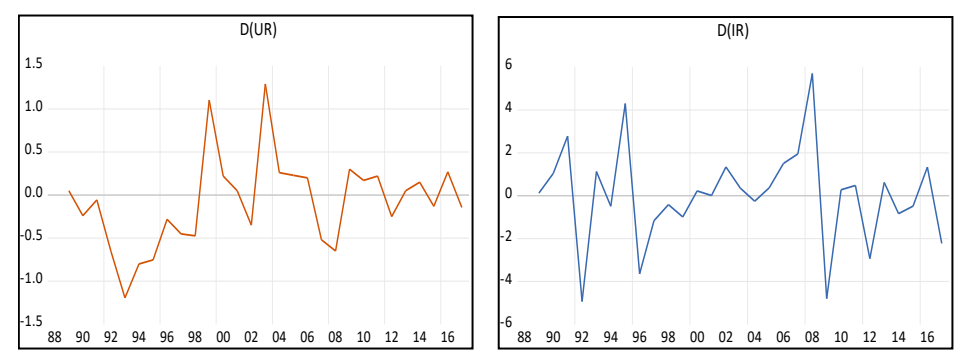

Figure 7. Variables conversion to stationary. 
Table 3. Multiple Breakpoint Test (Bai-Perron)

\begin{tabular}{lccc}
\hline Break Test & F-Statistics & Scaled F-statistics & Critical Value \\
\hline 0 vs. 1 & 19.05295 & 38.10591 & 11.47 \\
1 vs. 2 & 3.953683 & 7.907366 & 12.95 \\
Break dates: & & & \\
& & Repartition \\
1 & 2007 & 2007
\end{tabular}

Table 4. Optimal Lag Length Selection for the Johansen Test

\begin{tabular}{lcc} 
Lag Length & Akaike information Criterion (AIC) & Schwarz information Criterion (SC) \\
\hline 0 & 6.500747 & 6.698768 \\
1 & $5.789104^{*}$ & $6.179745^{*}$ \\
2 & 5.846971 & 6.432031 \\
3 & 6.014775 & 6.794855 \\
4 & & 7.171056 \\
5 & 6.195956 & 7.221483
\end{tabular}

Table 5. Johnson Co-Integration Test (1 Lag)

\begin{tabular}{|c|c|c|c|c|c|c|}
\hline $\begin{array}{l}\text { Hypoth- } \\
\text { esized No. of } \\
C E(s)\end{array}$ & Eigenvalue & $\begin{array}{c}\text { Trace Sta- } \\
\text { tistic }\end{array}$ & $\begin{array}{c}0.05 \text { Critical } \\
\text { Value }\end{array}$ & Eigenvalue & $\begin{array}{c}\text { Max-Eigen } \\
\text { Statistic }\end{array}$ & $\begin{array}{c}0.05 \text { Critical } \\
\text { Value }\end{array}$ \\
\hline None & 0.398580 & 21.14083 & 15.49471 & 0.398580 & 14.23694 & 14.26460 \\
\hline At most 1 & 0.218522 & 6.903896 & 3.841465 & 0.218522 & 6.903896 & 3.841465 \\
\hline
\end{tabular}


Table 6. Vector Error Correction Estimates

\section{Cointegrating Eq:}

$\operatorname{IR}(-1)$

UR (-1)

(0.35475)

$[-2.47424]$

C

Error Correction:

CointEq1

$-0.820537$

(0.22060)

[-3.71949]

$\mathrm{D}(\operatorname{IR}(-1))$

$-0.031321$

(0.18219)

$[-0.17191]$

$\mathrm{D}(\mathrm{UR}(-1))$

$-1.100118$

(0.72160)

$[-1.52455]$

C

$-1.146383$

(0.56200)

[-2.03982]

DUM

2.725763

(1.04259)

[2.61443]

R-squared

Adj. R-squared

Sum sq. resids

S.E. equation

F-statistic
0.452441

0.357213

82.12740

1.889645

4.751151
$\mathrm{D}(\mathrm{UR})$

0.061526

$(0.06161)$

[0.99867

0.017161

(0.05088)

[0.33730]

0.395647

(0.20152)

[1.96332]

0.017317

(0.15695)

[0.11034]

$-0.188866$

(0.29116)

[-0.64867]

0.167175

0.022335

6.405124

0.5277156

1.154209 
Table 6. Vector Error Correction Estimates (Continued)

\section{Cointegrating Eq:}

Log liklihood

Akaike AIC

Schwarz SC

Mean dependent

S.D. dependent

\section{CointEq1}

$-19.07879$

1.719914

1.957807

$-0.086929$

0.533710

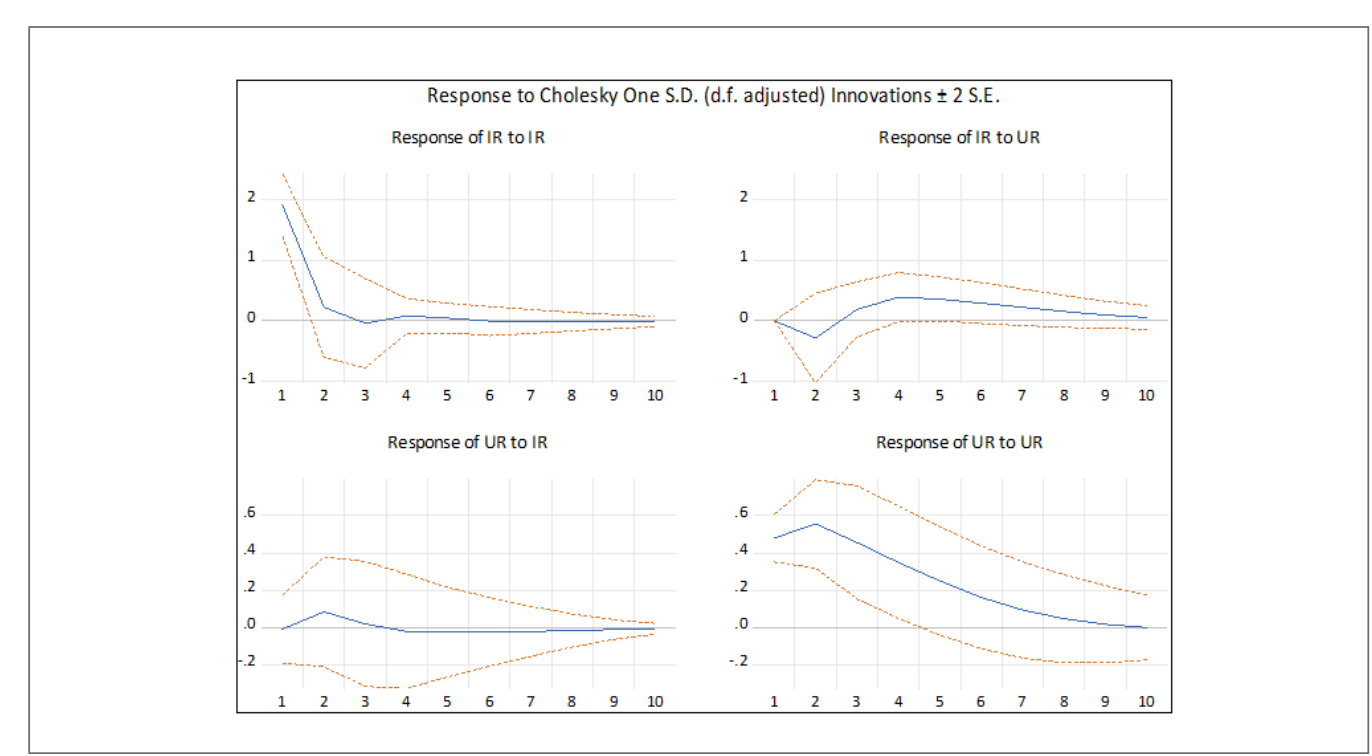

Figure 8. Impulse response functions (IRFs).

approximately $0.2 \%$ of decrease in the rate of inflation, reaching the lowest value of $-0.05 \%$ in the third year, then becomes positive and remaining close to the zero line. Unemployment response to the shock shows an initial negative change from zero to $-0.3 \%$, then found to be increasing to $0.4 \%$ during the fourth year. This response turns from negative to positive, with a stabilization of unemployment rate for the last five years. This expectation confirms Ossman (2014) forecasting of unemployment in the Kingdom for 2020 and 2030 to be nearly unchangeable (5.5\% and 5.55\% respectively). From the other side, given one positive shock to unemployment produces a rise from $0.5 \%$ to $0.8 \%$ as response in the rate of unemployment, then it 
starts degreasing till it reaches the level of zero during the tenth period. Inflation rates' response to the shock is zero, then $0.1 \%$ in the second year, starting after that to decline and become negative, being more stable and close to the level of zero. Inflation is expected to rises from 1.3 in 2017 to $3.71 \%$ in 2020 , then starts to decline slowly to reach $3.6 \%$ in 2030 .

\section{Conclusion}

An empirical investigation with respect to the tradeoff and twinning relationship among inflation and unemployment in the Kingdom of Saudi Arabia for the period 1988-2017 has been explored. The techniques of Augmented Dickey-Fuller (ADF) and Phillips Perron (P.P.) were carried out to test the unit root property of two variables series, which demonstrated that both inflation and unemployment considered to be integrated of the first order. Their residuals in the VAR representation appeared to be stationary. Johansen co-integration test indicated that there a long-run co-integrating relationship existed. In line with many previous studies in the literature (Furuoka, 2007; Kitov et al., 2013; Umaru and Zubairu, 2012), and based on VECM model, it is clear that there is a significant unidirectional long-run causality running from unemployment to inflation. This can be resulted as Saudi Autorities worried more about its youth unemployment, putting its possible efforts to control it more than inflation specially within its long-run visions and strategies. Yet Contrary to most studies that confirm the existence of a short-run association (Friedman, 1968; Karahan et al., 2012; King \& Watson, 1994) Wald test based on VECM result suggests the absence of short-run causality between inflation and unemployment.

In this respect, with the evidence of week Phillips curve relationship, the Saudi government's goal of price stability requires action to cure the priority of unemployment problems. With no causal effect of unemployment on inflation in the short term, but mainly on the long term, enjoying price stability will not harm employment level in the short term. Instead, long-run reform efforts and the new economic strategies should focus more on labor market reforms. With a high rate of unemployment among Saudi nationals, economic reform requires provision of accurate updated of labor market information; educational outcomes need to satisfy market requirements; productive job opportunities should be created. Additionally, self-employment and entrepreneurship should be encouraged and the sustainability of small and medium enterprises has to be supported. On the other hand, the goal of achieving full employment and reducing unemployment over the long term, maintaining the stability of general level requires reduction in overall demand-oriented consumption; raising motivation and awareness of savings; stimulating investment demand; and chasing the underling imbalance of Saudi economy, particularly high dependency on oil, which affects prices' stability.

\section{References}

Al Khateeb, T.T. (2014). Economic and social impact of rising prices: Case of Saudi Arabia. International Journal of Business and Management Studies, 3(1), 15-35.

Al Omran, A. (2010). Unemployment in Saudi Arabia: A serious issue for the Saudi youth. London Business School. Retrieved from: http:// twitmails3.s3-website-eu-west-1.amazonaws. com/users/237286227/3/attachment/Unemployment\%20In\%20Saudi\%20Arabia\%20\%28version $\% 202 \% 29$.pdf

Al Rasasi, M., \& Banafea, W. A. (2015). The effects of oil shocks on the Saudi Arabian economy. The Journal of Energy and Development, 41(1/2), 3145.

Alamoudi, R., Balubaid, M., and Siddiqui, A. (2015). Use of multiple regression analysis to identify factors that affect the unemployment rate in the Kingdom of Saudi Arabia. Life Science Journal, 12(7), 15-22.

Al-Bassam, K. (1999). Domestic and external sources of inflation in Saudi Arabia: an empirical study. Journal of King Abdulaziz University: Economics and Administration, 13(1), 3-30.

Alhamad, H. S. (2014). The high cost of living in Saudi Arabia: Growth and inflation in a macroeconomic perspective. Inquiries Journal, 6(09).

Cashell, B. W (2004). Inflation and unemployment: What is the connection? Congressional Research Service. Davidson, P. (2009). John Maynard Keynes. Palgrave Macmillan.

Chaal-Dabi, I., Kiendrebeogo, Y., Lenoble, N., \& Mottagahi, L. (2014). Mena data book. World Bank Group. http://documents.worldbank.org/curated/ 
en/356391468299194045/MENA-data-book

Dickey, D., \& Fuller, W. (1981). Likelihood ratio tests for autoregressive time series with a unit root. Econometrica, 49(4), 1057-1072.

Friedman, M. (1968). The role of monetary policy. The American Economic Review, 58(1), 1-17.

Friedman, M. (1977). Nobel lecture: inflation and unemployment. Journal of political economy, 85(3), 451-472.

Furuoka, F. (2007). Does the "Phillips curve" really exist? New empirical evidence from Malaysia. Economics Bulletin, 5(16), 1-14.

Furuoka, F. (2008). Unemployment and inflation in the Philippines: New evidence from vector error correction model. Philippine Journal of development, 35(1), 93-106.

Furuoka, F., \& Munir, Q. (2014). Unemployment and inflation in Malaysia: Evidence from error correction model. Malaysian Journal of Business and Economics (MJBE), 1(1), 35-45

Gordon, R. J. (1970). Prices in 1970: The Horizontal Phillips Curve?. Brookings Papers on Economic Activity, 1970(3), 449-458.

Haider, M. Z., \& Dutta, C. B. (2012). Inflation-Unemployment Trade-off: Evidence from Bangladesh Economy. Asia-Pacific Journal of Management Research and Innovation, 8(3), 227-237.

Hall, R. E. (1979). A theory of the natural unemployment rate and the duration of employment. Journal of monetary economics, 5(2), 153-169.

Hart, R. A. (2003). Overtime working, the Phillips curve and the wage curve: British engineering, 1926-66. The Manchester School, 71(2), 97-112.

Hogan, M. V. (1998). Explaining the recent behavior of inflation and unemployment in the United States. IMF Working Paper, 145.

International Labour Organization (2012). Decent work indicators: concepts and definitions. International Labour Office, Geneva.

International Labour Organization (2016). World employment social outlook. International Labour Office, Geneva.

Johansen, S. (1988). Statistical analysis of cointegration vectors. Journal of economic dynamics and control, 12(2-3), 231-254.

Karahan, Ö., Çolak, O., \& Bölükbaşi, Ö. (2012). Tradeoff between inflation and unemployment in Turkey [Paper presentation]. The $6^{\text {th }}$ International Days of Statistics and Economics, Prague, Czech Republic.

King, R. G., \& Watson, M. W. (1994). The post-war US Phillips curve: a revisionist econometric history. In Carnegie-Rochester Conference Series on Public
Policy (pp. 157-219). North-Holland.

Kitov, I. (2006). Inflation, unemployment, labor force change in the USA. ECINEQ, Working Paper 28. https://doi.org/10.2139/ssrn.886662

Kitov, I., \& Kitov, O. (2013). Inflation, unemployment, and labor force: The Phillips curve and long-term Projections for Japan. SSRN Electronic Journal. https://ssrn.com/abstract=2317812

Kitov, I., Kitov, O., \& Donlinskaya, S. (2007). Relationship between inflation, unemployment and labor force change rate in France: Cointegration test. MPRA paper 2736. https://ideas.repec.org/p/pra/ mprapa/2736.html

Lisý, J., \& Muchová, E. (2014). Inflation vs. unemployment- Some polemic issues. European Scientific Journal, 1(Special issue), 379-384.

Llaudes, R. (2005). The Phillips curve and long-term unemployment. ECB Working Paper 441. https:// papers.ssrn.com/sol3/papers.cfm?abstract_ id $=648002$

Lucas Jr, R. E. (1972). Expectations and the neutrality of money. Journal of Economic Theory, 4(2), 103-124.

Lucas, R. (1976). Econometric policy evaluation: A critique. Carnegie-Rochester Conference Series on Public Policy, 1: 19-46.

Lütkepohl, H., Saikkonen, P., \& Trenkler, C. (2002). Maximum eigenvalue versus trace test for the cointegrating rank of a VAR process. Econometrics Journal, 4(2), 287-310.

Mahmood, Y., Bokhari, R., \& Aslam, M. (2013). Tradeoff between inflation, interest and unemployment rate of Pakistan: A cointegration analysis. Pakistan Journal of Commerce and Social Sciences, 7(3), 482-492.

Mankiw, N. G. (2001). The inexorable and mysterious trade-off between inflation and unemployment. The Economic Journal, 111(471), 45-61.

Meteb, A.M. (2017). Unemployment and economic growth in Saudi Arabia 2000-2015. International Journal of Economic and Finance, 9(9), 83-93.

Nitzan, J. (1990). Macroeconomic Perspectives on inflation and unemployment. McGill University Discussion Papers, 1-46.

Ormerod, P., Rosewell, B., \& Phelps, P. (2013). Inflation/unemployment regimes and the instability of the Phillips curve. Applied Economics, 45(12), 1519-1531. Doi: 10.1080/00036846.2011.628299.

Ossman, G. (2014). Effects of unemployment rate fluctuations on exchange, interest and inflation rates in the Kingdom of Saudi Arabia, State of Qatar, and United Arab Emirates. American Interna- 
tional Journal of Research in Humanities, Arts and Social Sciences, 35-58.

Pass, C., Lowes, B., Davies, L., \& Kronish, S.J. (1991). The harper collins dictionary of economics. Harper Perennial.

Phillips, A. W. (1958). The relation between unemployment and the rate of change of money wage rates in the United Kingdom, 1861-1957. Economica, 25(100), 283-299. Doi: https://doi. org/10.1111/j.1468-0335.1958.tb00003.x

Phillips, P. C., \& Perron, P. (1988). Testing for a unit root in time series regression. Biometrika, 75(2), 335-346.

Ramady, M. (2009). External and internal determinants of inflation: A case of Saudi Arabia. Middle East Journal of Economics and Finance, 2(1-2), 25-38.

Ramady, M. (2013). Gulf unemployment and government policies: prospects for the Saudi labour quota or Nitaqat. International Journal of Economics and Business Research, 5(4), 476-498. Doi: http:// doi.org/10.1504/ijebr.2013.054266

Riggi, M., \& Venditti, F. (2015). Failing to forecast low inflation and Phillips curve instability: A Euroarea perspective. International Finance, 18(1), 47-68.

Samba Financial Group (2010). Inflation in Saudi Arabia: Drivers, trends, and outlook. Samba Financial Group. https://www.arabdevelopmentportal. com/publication/inflation-saudi-arabia-driverstrends-and-outlook

Samuelson, P., \& Solow, R. (1960). Analytical aspects of anti-inflation policy. The American Economic Review, 50(2), 177-194. Doi: https://doi. org/10.2307/2309498

Saudi Arabian Monetary Agency (2015). Annual statistics. http://www.sama.gov.sa/ar-sa/EconomicReports/Pages/YearlyStatistics.aspx.

Saudi Ministry of Labor (2012). Annual statistics report. www.emol.gov.sa/nitaqat/files/manual.pdf.

Solow, R. (1970). Discussion of RJ Gordon's recent acceleration of inflation and its lessons for the future. Brookings Papers on Economic Activities, 1, 42-46.

Stock, J. H., \& Watson, M. W. (2008). Phillips curve inflation forecasts. National Bureau of Economic Research, w14322. https://doi.org/10.3386/w14322

Systemic Disorder (2015). Real unemployment is double the 'official' unemployment rate. Systemic Disorder. https://systemicdisorder.wordpress. com/2015/03/18/unemployment-double-officialrate/
Umaru, A., \& Zubairu, A. (2012). An empirical analysis of the relationship between unemployment and inflation in Nigrtia from 1977-2009. Economics and Finance Review, 1(12), 42-61.

World Bank (2018). Inflation, consumer price (annual \%). [Data set]. https://data.worldbank.org/indicator/FP.CPI.TOTL.ZG.

World Bank (2018). Unemployment, total (\% of total labor force), modeled ILO estimate. [Data set] https://data.worldbank.org/indicator/SL.UEM. TOTL.ZS. 